И. А. Слободняк

Байкальский государственный университет,

г. Иркутск, Российская Федерация

э. В. Грозина

Байкальский государственный университет,

г. Иркутск, Российская Федерация

А. А. Фадеева

Байкальский государственный университет,

г. Иркутск, Российская Федерация

\title{
ПРОБЛЕМЫ РАСЧЕТА И АНАЛИЗА ЧИСТЫХ АКТИВОВ ОРГАНИЗАЦИЙ
}

\begin{abstract}
АНнОТАЦИЯ. Чистые активы являются одним из важнейших показателей оценки финансового состояния, от их уровня зависит само существование организации. В статье систематизированы основные подходы к анализу чистых активов, встречающиеся в экономической литературе. Проведенная систематизация позволила выявить направления анализа чистых активов, показатели, характеризующие эффективность их использования, факторы, влияющие на их величину. Также проанализирована методика расчета чистых активов с учетом вносимых в нее в течение 1996-2016 гг. изменений. Действующий в настоящее время порядок расчета чистых активов, по мнению авторов публикации, является достаточно корректным. Рассмотрены дискуссионные вопросы, связанные с отражением в бухгалтерской отчетности информации о доходах будущих периодов. Доказана необходимость дифференцированного подхода к классификации отдельных составляющих статьи бухгалтерского баланса «Доходы будущих периодов» в качестве капитала/обязательства.

кЛЮчЕВЫЕ слОВА. Чистые активы; доходы будущих периодов; бухгалтерский баланс; бухгалтерский учет; анализ финансовой отчетности.

ФИНАНСИРОВАНИЕ. Работа выполнена при финансовой поддержке государственного задания № 2014/52 на выполнение государственных работ в сфере научной деятельности в рамках базовой части проекта № 597 «Разработка методологии финансового обеспечения социально значимых расходов» (номер госрегистрации в ФГАНУ ЦИТиС 01201458899).

ИНФОРМАЦИЯ О СТАТЬЕ. Дата поступления 27 октября 2016 г.; дата принятия к печати 15 ноября 2016 г.; дата онлайн-размещения 30 ноября 2016 г.
\end{abstract}

I. A. Slobodnyk Baikal State University, Irkutsk, Russian Federation

E. V. Grozina Baikal State University, Irkutsk, Russian Federation

A. A. Fadeeva Baikal State University, Irkutsk, Russian Federation

\section{PROBLEMS OF CALCULATING AND ANALYZING ORGANIZATIONS' NET ASSETS}

ABSTRACT. Net assets is one of the most important indicators of assessing the financial condition, their level determines the very existence of the organization. The article systemizes the main approaches to analyzing net assets met in the economic literature. The systemization made allows to specify the directions for analyzing the net assets, the indicators that characterize the efficiency of their use, the factors that affect their

(C) И. А. Слободняк, Э. В. Грозина, А. А. Фадеева, 2016

\section{Baikal Research Journal}


amount. The article also analyses the method of calculating the net assets in view of the changes made during the period of 1996-2016. The net asset calculation procedure existing at the present time, in the authors' opinion, is sufficiently correct. The article considers the disputing issues related to presenting information about incomes of future periods in accounting. It proves the necessity of a differential approach to classification of separate constituent articles of the accounting balance «Incomes of Future Periods" as a kind of capital/obligating document.

KEYWORDS. Net assets; incomes of future periods; accounting balance; accounting; analysis of accounting statements.

FINANCING. Governmental order No. 2014/52 on performance of state work in research activities within the base part of the project No. 597 «Devising the methodology of socially important expenses financial support» (registration No. in FGANU TsITiS 01201458899).

ARTICLE INFO. Received October 27, 2016; accepted November 15, 2016; available online November 30, 2016.

Чистые активы являются важнейшим критерием оценки финансовой устойчивости и платежеспособности организации. Фактически на сегодняшний день чистые активы - один из немногих показателей, который не просто рассчитывается, а затем сравнивается с каким-либо ориентиром, но используется при регулировании деятельности организации в части формирования структуры капитала хозяйствующих субъектов. Причем несоблюдение установленных законодательством условий может иметь для организации самые негативные последствия вплоть до прямого запрета на ее функционирование и последующую ликвидацию. В то же время заметим, что порядок расчета чистых активов организации все еще остается дискуссионным, несмотря на существование официальной методики их расчета, которая должна была бы расставить все точки над «і». Но вместо этого утверждение действующей на сегодняшний день методики привело к новому витку дискуссии о составе таких важнейших элементов финансовой отчетности как капитал и обязательства, что привело к появлению в научных публикациях требований о необходимости радикального пересмотра вообще структуры пассива бухгалтерского баланса. Все вышесказанное определяет актуальность темы данной статьи, основной задачей которой является доказательство обоснованности современного подхода к расчету чистых активов, а также выработка рекомендаций по реформированию нормативно-правовой базы бухгалтерского учета.

Понятие чистых активов в современной российской практике было введено в 1994 г. Гражданским кодексом РФ для оценки степени ликвидности полных товариществ, обществ с ограниченной ответственностью, акционерных обществ и унитарных предприятий, основанных на праве хозяйственного ведения.

Начиная с 1995 г. показатель чистых активов стал обязательным для расчета в составе бухгалтерской отчетности предприятий всех организационно-правовых форм.

Методика расчета чистых активов организации в 1995-2016 гг. регламентировалась следующими нормативными актами: приказом Министерства финансов РФ «O порядке отражения в бухгалтерском учете отдельных операций, связанных с введением в действие первой части Гражданского кодекса РФ» от 28 июля 1995 г. № 81; приказом Минфина РФ «О порядке оценки стоимости чистых активов акционерных обществ» от 29 марта 1996 г. № 33; приказом Минфина РФ «О Порядке оценки стоимости чистых активов акционерных обществ» от 5 августа 1996 г. № 71, ФКЦБ РФ № 149; приказом Минфина РФ «Об утверждении порядка оценки стоимости чистых активов акционерных обществ» от 29 января 2003 г. № 10н, ФКЦБ РФ № 03-6/пз; приказом Минфина России «Об утверждении Порядка определения стоимости чистых активов» от 28 августа 2014 г. № 84н (табл. 1).

\section{Baikal Research Journal}


Таблица 1

Методика расчета чистых активов организации

\begin{tabular}{|c|c|c|c|c|}
\hline $\begin{array}{l}\text { Активы / } \\
\text { Пассивы }\end{array}$ & $\begin{array}{c}\text { Приказ Минфина } \\
\text { № } 81 \text { (№ 33). }\end{array}$ & $\begin{array}{c}\text { Приказ Минфина РФ } \\
\text { № 71, ФКЦБ РФ } \\
\text { № } 149\end{array}$ & $\begin{array}{c}\text { Приказ Минфина } \\
\text { РФ № 10н, ФКЦБ } \\
\text { РФ № 03-6/пз }\end{array}$ & $\begin{array}{c}\text { Приказ Минфина } \\
\text { России № } 84 \mathrm{H}\end{array}$ \\
\hline $\begin{array}{l}\text { Чистые } \\
\text { активы }\end{array}$ & $\begin{array}{l}\text { Величина, опре- } \\
\text { деляемая путем } \\
\text { вычитания из суммы } \\
\text { активов организа- } \\
\text { ции, принимаемых } \\
\text { к расчету, суммы ее } \\
\text { обязательств, прини- } \\
\text { маемых к расчету }\end{array}$ & $\begin{array}{l}\text { Величина, определяе- } \\
\text { мая путем вычитания } \\
\text { из суммы активов } \\
\text { акционерного обще- } \\
\text { ства, принимаемых } \\
\text { к расчету, суммы его } \\
\text { обязательств, прини- } \\
\text { маемых к расчету }\end{array}$ & $\begin{array}{l}\text { Величина, определя- } \\
\text { емая путем вычи- } \\
\text { тания из суммы ак- } \\
\text { тивов акционерного } \\
\text { общества, прини- } \\
\text { маемых к расчету, } \\
\text { суммы его пассивов, } \\
\text { принимаемых к } \\
\text { расчету }\end{array}$ & $\begin{array}{l}\text { Разность меж- } \\
\text { ду величиной } \\
\text { принимаемых к } \\
\text { расчету активов } \\
\text { организации и } \\
\text { величиной при- } \\
\text { нимаемых к рас- } \\
\text { чету обязательств } \\
\text { организации }\end{array}$ \\
\hline $\begin{array}{l}\text { Прини- } \\
\text { маемые } \\
\text { к расчету } \\
\text { активы }\end{array}$ & $\begin{array}{l}\text { Основные средства и } \\
\text { иные внеоборотные } \\
\text { активы, отражаемые } \\
\text { в первом разделе } \\
\text { актива баланса, кро- } \\
\text { ме задолженности } \\
\text { участников (учреди- } \\
\text { телей) по их вкладам } \\
\text { в уставный капитал. } \\
\text { Запасы и затраты, } \\
\text { отражаемые во вто- } \\
\text { ром разделе актива } \\
\text { баланса. } \\
\text { Денежные средства, } \\
\text { расчеты и прочие ак- } \\
\text { тивы, показываемые } \\
\text { в третьем разделе } \\
\text { актива баланса }\end{array}$ & $\begin{array}{l}\text { Внеоборотные акти- } \\
\text { вы, отражаемые в } \\
\text { первом разделе балан- } \\
\text { са, за исключением } \\
\text { балансовой стоимости } \\
\text { собственных акций } \\
\text { общества, выкуплен- } \\
\text { ных у акционеров. } \\
\text { Запасы и затраты, } \\
\text { денежные средства, } \\
\text { расчеты и прочие } \\
\text { активы, показывае- } \\
\text { мые во втором раз- } \\
\text { деле бухгалтерского } \\
\text { баланса, за исключе- } \\
\text { нием задолженности } \\
\text { участников (учреди- } \\
\text { телей) по их вкладам } \\
\text { в уставный капитал и } \\
\text { балансовой стоимости } \\
\text { собственных акций, } \\
\text { выкупленных у акци- } \\
\text { онеров }\end{array}$ & $\begin{array}{l}\text { Внеоборотные акти- } \\
\text { вы, отражаемые в } \\
\text { первом разделе бух- } \\
\text { галтерского баланса. } \\
\text { Оборотные акти- } \\
\text { вы, отражаемые } \\
\text { во втором разделе } \\
\text { бухгалтерского } \\
\text { баланса, за исклю- } \\
\text { чением стоимости в } \\
\text { сумме фактических } \\
\text { затрат на выкуп } \\
\text { собственных акций, } \\
\text { выкупленных акци- } \\
\text { онерным обществом } \\
\text { у акционеров для } \\
\text { их последующей } \\
\text { перепродажи или } \\
\text { аннулирования, } \\
\text { и задолженности } \\
\text { участников (учреди- } \\
\text { телей) по взносам в } \\
\text { уставный капитал }\end{array}$ & $\begin{array}{l}\text { Все активы } \\
\text { организации, } \\
\text { за исключени- } \\
\text { ем дебиторской } \\
\text { задолженности } \\
\text { учредителей } \\
\text { (участников, } \\
\text { акционеров, } \\
\text { собственников, } \\
\text { членов) по взно- } \\
\text { сам (вкладам) в } \\
\text { уставный капи- } \\
\text { тал (уставный } \\
\text { фонд, паевой } \\
\text { фонд, складоч- } \\
\text { ный капитал), по } \\
\text { оплате акций }\end{array}$ \\
\hline $\begin{array}{l}\text { Прини- } \\
\text { маемые } \\
\text { к расчету } \\
\text { обяза- } \\
\text { тельства } \\
\text { (пассивы) }\end{array}$ & $\begin{array}{l}\text { Статьи первого } \\
\text { раздела пассива ба- } \\
\text { ланса, характеризу- } \\
\text { ющие обязательства } \\
\text { организации (целе- } \\
\text { вые финансирова- } \\
\text { ние и поступления; } \\
\text { арендные обязатель- } \\
\text { ства). } \\
\text { Статьи второго раз- } \\
\text { дела пассива балан- } \\
\text { са - долгосрочные и } \\
\text { краткосрочные обя- } \\
\text { зательства банкам и } \\
\text { иным юридическим } \\
\text { и физическим ли- } \\
\text { цам; расчеты и про- } \\
\text { чие пассивы, кроме } \\
\text { сумм, отраженных } \\
\text { по статьям «Резервы } \\
\text { по сомнительным } \\
\text { долгам» и «Доходы } \\
\text { будущих периодов» }\end{array}$ & $\begin{array}{l}\text { Статья четвертого } \\
\text { раздела бухгалтерско- } \\
\text { го баланса - целевые } \\
\text { финансирование и } \\
\text { поступления. } \\
\text { Статьи пятого раздела } \\
\text { баланса - долгосроч- } \\
\text { ные обязательства } \\
\text { банкам и иным юри- } \\
\text { дическим и физиче- } \\
\text { ским лицам. } \\
\text { Статьи шестого раз- } \\
\text { дела баланса - кра- } \\
\text { ткосрочные обяза- } \\
\text { тельства банкам и } \\
\text { иным юридическим } \\
\text { и физическим лицам; } \\
\text { расчеты и прочие пас- } \\
\text { сивы, кроме сумм, от- } \\
\text { раженных по статьям } \\
\text { «Доходы будущих } \\
\text { периодов» и «Фонды } \\
\text { потребления» }\end{array}$ & $\begin{array}{l}\text { Долгосрочные обяза- } \\
\text { тельства по займам } \\
\text { и кредитам и про- } \\
\text { чие долгосрочные } \\
\text { обязательства. } \\
\text { Краткосрочные } \\
\text { обязательства по } \\
\text { займам и кредитам. } \\
\text { Кредиторская задол- } \\
\text { женность. } \\
\text { Задолженность } \\
\text { участникам (учреди- } \\
\text { телям) по выплате } \\
\text { доходов. } \\
\text { Резервы предстоя- } \\
\text { щих расходов. } \\
\text { Прочие краткосроч- } \\
\text { ные обязательства }\end{array}$ & $\begin{array}{l}\text { Все обязательства } \\
\text { организации, за } \\
\text { исключением } \\
\text { доходов будущих } \\
\text { периодов, при- } \\
\text { знанных органи- } \\
\text { зацией в связи } \\
\text { с получением } \\
\text { государственной } \\
\text { помощи, а также } \\
\text { в связи с безвоз- } \\
\text { мездным получе- } \\
\text { нием имущества }\end{array}$ \\
\hline
\end{tabular}

\section{Baikal Research Journal}

электронный научный журнал Байкальского государственного университета 
В соответствии с этими нормативными документами чистые активы определись путем вычитания из суммы активов, принимаемых к расчету, суммы обязательств (пассивов), принимаемых к расчету. При этом алгоритм определения принимаемых к расчету активов и обязательств (пассивов) менялся связи с внесением изменений в методику бухгалтерского учета и порядок составления бухгалтерской отчетности организации (приказ Минфина РФ «О годовой бухгалтерской отчетности организаций» от 12 ноября 1996 г. № 97, приказ Минфина РФ «О формах бухгалтерской отчетности организаций» от 13 января 2000 г. № 4н, приказ Минфина РФ «О формах бухгалтерской отчетности организаций» от 22 июля 2003 г. № 67н, приказ Минфина России «О формах бухгалтерской отчетности организаций» от 2 июля 2010 г. № $66 \mathrm{H})$.

Следует отметить, что в других нормативных актах встречалась несколько иная методика расчета активов и обязательств (пассивов), принимаемых к расчету чистых активов. В частности, в Методических рекомендациях Федеральной службы России по делам о несостоятельности и финансовому оздоровлению от 8 октября 1999 г. № 33-р было установлено, что величина участвующих в расчете активов должна быть уменьшена на сумму статьи «НДС по приобретенным ценностям». В пассивы организации, принимаемые для расчета чистых активов, не включалась вместе со статьей «Доходы будущих периодов» статья «Резервы предстоящих расходов» (после внесения изменений в ПБУ 8/2010 и соответствующих изменений в содержание бухгалтерской отчетности данная статья была заменена статьей «Оценочные обязательства»). Именно необходимость включения в состав обязательств организации данных по указанным двум статьям бухгалтерской отчетности и является одной из ключевых проблем методики расчета чистых активов. Что касается включения в состав пассивов, принимаемых к расчету, сумм оценочных обязательств, то данный вопрос подробно был рассмотрен И. А. Слободняком, Э. В. Грозиной и Т. Л. Быковой в статье «Учетно-аналитическая информация об оценочных обязательствах", где была обоснована необходимость включения в состав обязательств организации (а соответственно и пассивов, принимаемых к расчету) сумм оценочных обязательств [1]. В то же время принадлежность доходов будущих периодов, как и вообще целесообразность данного элемента финансовой отчетности, до сих пор остается актуальной.

В настоящее время в составе доходов будущих периодов учитываются:

- доходы, полученные в счет будущих периодов;

- доходы, связанные с получением государственной помощи;

- безвозмездные поступления;

- предстоящие поступления задолженности по недостачам, выявленным за прошлые периоды;

- разница между суммой, подлежащей взысканию с виновных лиц, и балансовой стоимостью по недостаче материальных ценностей [2].

При этом необходимо заметить, что с 1 января 2011 г. использование счета 98 строго ограничивается ситуациями, которые прямо предусмотрены нормативными документами по бухгалтерскому учету (в которых и можно обнаружить указания на приведенный выше список). Что же касается других составляющих, которые ранее традиционно включались в состав доходов будущих периодов, то ряд авторов полагает, в частности, при получении авансовых платежей по арендной плате для отражения предстоящих поступлений задолженности по недостачам, выявленным за прошлые годы, в случаях образования разницы между суммой, подлежащей взысканию с виновных лиц, и балансовой стоимостью по недостачам ценностей, применение счета 98 «Доходы будущих периодов» нецелесообразно,

\section{Baikal Research Journal}

электронный научный журнал Байкальского государственного университета 
поскольку это не отвечает действующим на сегодняшний день положениям по бухгалтерскому учету [3].

При этом следует заметить, что статья «Доходы будущих периодов» вообще отсутствует в отчетности, составленной в соответствии с требованиями международных стандартов финансовой отчетности (МСФО). МСФО, относя суммы, признаваемые в РФ в качестве доходов будущих периодов, к обязательствам, подразумевают, что это такие доходы компании, которые она получила, но еще не заработала. Следовательно, когда доходы будущих периодов будут трансформироваться в прибыль отчетного года (т. е. обязательство будет трансформироваться в капитал), компания однозначно понесет потери в виде оттока ресурсов, содержащих экономические выгоды, тем самым заработав эти доходы [4]. Это приводит к необходимости реклассификации соответствующих сумм, представленных в отчетности российских организации, при ее трансформации в формат МСФО.

Существует еще более радикальная позиция, обозначенная в работах Г. И. Алексеевой. В своих более ранних публикациях, вышедших после изменения Положения по ведению бухгалтерского учета и отчетности в РФ от 28 июля 1998 г. № 34н (с изменениями от 24 декабря 2010 г.), суть которых состоит в исключении упоминания соответствующего объекта в указанном положении, Г. И. Алексеева вообще пришла к выводу о необходимости прекращения учета доходов будущих периодов. Данная позиция обосновывалась тем, что в подобных ситуациях Минфин традиционно ориентируется на действие принципа приоритета нормы, принятой позднее. Соответственно, исключение из Положения № $34 \mathrm{H}$ категории «доходы будущих периодов» автоматически влечет за собой прекращение использования данной категории в бухгалтерском учете независимо от того, что она по-прежнему упоминается в ранее утвержденных нормативных документах. Следовательно, в зависимости от ситуации в бухгалтерском учете должны признаваться не доходы будущих периодов, а либо доход текущего периода, либо обязательство. В результате, Г. И. Алексеева предлагала изъять категорию «доходы будущих периодов» из п. 9 ПБУ 13/2000, п. 29 Методических указаний по бухгалтерскому учету основных средств, п. 4 Указаний об отражении в бухгалтерском учете операции по договору лизинга с редакцией данных документов в соответствии с МСФО. Более того, из Плана счетов бухгалтерского учета финансово-хозяйственной деятельности организаций и Инструкции по применению Плана счетов необходимо исключить счет 98 «Доходы будущих периодов» [5].

Однако в более поздних публикациях описанная выше позиция была смягчена. Например, в 2015 г. Г. И. Алексеева и Э. С. Алексеев высказали мнение, что исключение понятия «доходы будущих периодов» из Положения № 34 н не привело к отмене самого факта возникновения таких доходов в практической деятельности организаций. Следовательно, в составе доходов будущих периодов должны учитываться не любые суммы поступлений, которые по тем или иным причинам могут рассматриваться бухгалтером в качестве доходов будущих периодов, а только их ограниченный состав. То есть изъятие из Положения № 34 н определения доходов будущих периодов не означает отмену понятия «доходы будущих периодов», а лишь ограничивает использование счета 98 «Доходы будущих периодов». Он может использоваться только в тех ситуациях, которые содержатся в нормативных документах.

При этом пока не утверждены федеральные стандарты бухгалтерского учета, следует руководствоваться правилами, закрепленными в действующих нормативных документах. Это указано и в п. 7 Положения по бухгалтерскому учету «Учетная политика организации» (ПБУ 1/2008), а именно: если по конкретному

\section{Baikal Research Journal}


вопросу непосредственное регулирование отсутствует, то организация вправе самостоятельно разрабатывать правила учета по аналогии с действующими нормативными требованиями либо использовать решения, закрепленные в МСФО, введенными в действие на территории РФ [6].

В бухгалтерском балансе российских организаций величина доходов будущих периодов отражается в разделе V по аналогичной статье, а, значит, в соответствии с названием указанного раздела должна включаться в состав краткосрочных обязательств организации. Однако, исследование лишь списка основных составляющих доходов будущих периодов приводит к выводу о том, что их состав неоднороден. Например, доходы, полученные в счет будущих периодов, более верно отнести к обязательствам организации, поскольку после получения соответствующих сумм организация должна выполнить определенные операции. Следовательно, данные суммы достаточно логично показывать именно в составе краткосрочных обязательств в соответствующем разделе баланса.

Наоборот, суммы доходов будущих периодов, признанные в результате безвозмездного получения имущества, справедливо раскрывать именно в составе капитала, поскольку они не требуют каких-либо ответных действий со стороны организации.

Наибольшие споры возникают вокруг классификации в качестве обязательства/капитала доходов будущих периодов, возникающих в связи с погашением виновными лицами сумм недостач имущества по рыночным ценам. С одной стороны, организация не должна совершать дополнительные действия по получению соответствующих сумм (это признанные суммы долга, которые будут погашены материально-ответственным лицом позднее). Следовательно, их можно было бы прямо показывать в составе капитала в соответствии с допущением метода начисления.

С другой стороны, фактическое получение данных сумм еще отсутствует (причем в ряде случаев сохраняются существенные риски непогашения соответствующих долгов), а потому признавать их сразу в составе капитала также не до конца оправдано. В этой связи можно только приветствовать дифференцированный подход к классификации соответствующей статьи в качестве капитала/обязательства, что закреплено в действующем в настоящее время порядок определения стоимости чистых активов, который вступил в силу с 4 ноября 2014 г.

В настоящее время система расчета чистых активов одинакова как для акционерных обществ, так и для других организаций независимо от их организационно-правовой формы, применяемой системы налогообложения и формы собственности. В целом расчет чистых активов остался прежним. Как и ранее, стоимость чистых активов определяется по данным бухгалтерского учета и равна разнице между активами организации и ее обязательствами. В ранее действующем Порядке оценки стоимости чистых активов из активов организации вычитались фактические затраты на выкуп собственных акций АО у акционеров для их последующей перепродажи и аннулирования. Однако в связи с тем, что в настоящее время эти затраты указываются в пассиве баланса, корректировать сумму активов нет необходимости. Принимаемые к расчету обязательства включают все обязательства организации, за исключением не всех доходов будущих периодов, как было ранее, а только признанных организацией в связи с получением государственной помощи, а также в связи с безвозмездным получением имущества. Подробный анализ нового порядка расчета чистых активов был проведен в ряде работ, например, в работах С. А. Верещагина и С. М. Линейкиной [7; 8].

Однако важно не просто рассчитать величину чистых активов, но и подвергнуть ее всестороннему анализу, а также определить влияние доходов будущих

\section{Baikal Research Journal}

электронный научный журнал Байкальского государственного университета 
периодов на финансовое состояние организации. В настоящее время отсутствует типовая методика анализа чистых активов. В экономической литературе представлены следующие направления анализа чистых активов:

- анализ динамики чистых активов [9-16];

- оценка реальности динамики чистых активов [13; 14];

- выявление и оценка факторов, влияющих на изменение стоимости чистых активов [12];

- анализ эффективности использования чистых активов [9; 13- 17];

- оценка соотношений чистых активов и уставного капитала, чистых активов и суммы уставного и резервного капитала и др. [10-18].

Остановимся на каждом из этих направлений анализа.

При оценке динамики чистых активов некорректно механически сравнивать величины чистых активов за анализируемый период без учета уровня инфляции. В работе коллектива авторов под редакцией О. В. Ефимовой, М. В. Мельник предлагается определить расчетную величину чистых активов на конец года, которая соответствует чистым активам на начало года с учетом падения их покупательной способности [10, с. 295]:

$$
Ч A_{\text {к.г(расчет) }}=Ч A_{\text {н.г. }} \frac{\text { Индекс иен на конец отчетного периода }}{\text { Индекс иен на начало отчетного периода }},
$$

где Ч $A_{\text {к.г.(расчет) }}$ - расчетная величина чистых активов на конец года; $Ч A_{\text {н.г. }}$ - величина чистых активов на начало года.

В работе Т. А. Пожидаевой предлагается оценить реальность динамики чистых активов, так как значительное их увеличение на конец периода может оказаться несущественным по сравнению с ростом совокупных активов. Для этого необходимо рассчитать соотношение чистых и совокупных активов на начало и конец отчетного периода [14, с. 72].

В процессе анализа чистых активов необходимо выявить и оценить факторы, влияющие на их величину. С точки зрения влияния на стоимость чистых активов (СЧА) изменения статей баланса, по мнению В. Г. Когденко, можно разделить на три группы:

- изменения в активах и обязательствах, которые не ведут к изменению СЧА (приобретение активов за счет возникновения обязательств, погашение обязательств за счет перевода активов и др.);

- изменения в активах и обязательствах, которые ведут к изменению СЧА (взносы участников (учредителей) в уставный капитал, переоценка основных средств и др.);

- изменения составляющих собственного капитала, которые не затрагивают активы, обязательства и СЧА (уменьшение номинальной стоимости акций, направление нераспределенной прибыли в резервный капитал и др.) [12, с. 87].

Факторный анализ изменения стоимости чистых активов проводится с использованием аддитивной модели:

$$
C Ч A=У К-A_{s}+\Pi_{B A}+Д К+P К+H \Pi-У-3_{y s}+Д Б \Pi,
$$

где УК - уставный капитал; $A_{b}-$ собственные акции, выкупленные у акционеров; $\Pi_{B A}-$ переоценка внеоборотных активов; $Д K-$ добавочный капитал; $P K-$ резервный капитал; $Н П$ - нераспределенная прибыль; У - непокрытый убыток; $3_{y в}$ - задолженность участников (учредителей) по взносам в уставный капитал; ДБП - доходы будущих периодов, признанные в связи с получением государственной помощи и безвозмездным получением имущества.

\section{Baikal Research Journal}


Важнейшее направление анализа - оценка эффективности использования чистых активов. Для этого анализируют в динамике и проводят факторный анализ следующих показателей:

- оборачиваемость (отдача) чистых активов

$$
K_{\text {पA }}=\frac{N}{4 A},
$$

где $N$ - выручка; ЧА - среднегодовая стоимость чистых активов;

- рентабельность чистых активов

$$
R_{\text {ЧA }}=\frac{P}{\Psi A},
$$

где $P$ - чистая прибыль.

При этом в экономической литературе представлены разные факторные модели. Так, в работе Э. А. Маркарьяна, Г. П. Герасименко, С. Э. Маркарьяна для факторного анализа чистых активов предлагается использовать следующую факторную модель [13, с. 269-270]:

$$
R_{\text {पA }}=\frac{P}{\Psi A}=\frac{P}{N} \cdot \frac{N}{\Psi A}=R_{N} K_{\text {पA }},
$$

где $R_{N}=P / N-$ рентабельность продаж.

Как видно из модели (1), рентабельность чистых активов зависит от изменения рентабельности продаж и оборачиваемости чистых активов. Влияние факторов на изменение рентабельности чистых активов можно определить способом абсолютных разниц:

$$
\begin{gathered}
\Delta R_{\Psi_{A}}\left(\Delta R_{N}\right)=\Delta R_{N} K_{ч_{A_{0}}} ; \\
\Delta R_{\Psi_{A}}\left(\Delta K_{\Psi_{A}}\right)=R_{N_{1}} \Delta K_{\Psi_{A}} .
\end{gathered}
$$

В свою очередь на изменение рентабельности продаж оказывают влияние изменение структуры и ассортимента продаж, изменение себестоимости реализации, а также изменение цен продаж.

Изменение оборачиваемости чистых активов в свою очередь обусловливается влиянием ряда факторов, что видно из следующей факторной модели:

$$
K_{\text {ЧA }_{1}}=\frac{N}{Ч A}=\frac{C K}{Ч A} \cdot \frac{3 K}{C K} \cdot \frac{O A}{3 K} \cdot \frac{N}{O A}=K_{c} \cdot K_{\phi a} \cdot K_{n} \cdot K_{O A},
$$

где $K_{c}=C K / Ч A-$ коэффициент соотношения собственного капитала и чистых активов; $K_{\phi a}=3 \kappa / C K-$ коэффициент финансовой активности; $K_{n}=O A / 3 K-$ коэффициент покрытия заемного капитала оборотными активами; $K_{O A}=N / O A-$ коэффициент оборачиваемости оборотных активов.

В работе Л. А. Адамайтис для расчета влияния факторов на показатель рентабельности чистых активов используется трехфакторная мультипликативная модель [9, с. 179]:

$$
R_{\text {ЧA }_{A}}=\frac{P}{\Psi A}=\frac{P}{N} \cdot \frac{N}{3 K} \cdot \frac{3 K}{Ч A}=R_{N} K_{O B_{3 K}} K_{\phi},
$$

где $\kappa_{O Б_{3 K}}=N / 3 K-$ коэффициент оборачиваемости заемного капитала; $K_{\phi}=3 \kappa / Ч A-$ коэффициент соотношения заемного капитала и чистых активов (финансовой структуры).

В работе коллектива авторов под редакцией Н. В. Войтоловского, А. П. Калининой, И. И. Мазуровой модель, представленную формулой (5), предлагается расширить [16, с. 430-431]:

\section{Baikal Research Journal}




$$
R_{\Psi_{A}}=\frac{P}{\Psi A}=\frac{A}{\Psi A} \cdot \frac{A_{p}}{A} \cdot \frac{A_{n}}{A_{p}} \cdot \frac{N}{A_{n}} \cdot \frac{P}{N}=K_{a} y_{p} y_{n} K_{O B_{A I I}} R_{N},
$$

где $K_{a}=A / Ч A-$ коэффициент соотношения совокупных активов и чистых активов; $\mathrm{V}_{p}=A_{p} / A-$ удельный вес активов, реально находящихся в обороте организации, в стоимости совокупных активов; $y_{n}=A_{n} / A_{p}-$ удельный вес активов, используемых в предпринимательской деятельности, в стоимости активов, реально находящихся в обороте организации; $K_{O D_{A I}}=N / A_{n}$ - коэффициент оборачиваемости активов, используемых в предпринимательской деятельности.

Расчет влияния каждого фактора, предусмотренного в модели (2), на изменение рентабельности чистых активов можно осуществить с помощью традиционных способов экономического анализа.

В работе коллектива авторов под редакцией Л. Т. Гиляровской представлено следующее моделирование показателя рентабельности чистых активов [17, с. 132]:

$$
R_{\Psi_{A}}=\frac{P}{\Psi A}=\frac{P}{N} \cdot \frac{N}{O A} \cdot \frac{O A}{\kappa O} \cdot \frac{\kappa O}{\not 3} \cdot \frac{\not 3}{\kappa 3} \cdot \frac{\kappa 3}{3 \kappa} \cdot \frac{3 \kappa}{\Psi A}=R_{N} K_{O A} K_{m n} \kappa_{0} K_{\partial} K_{\kappa} K_{\phi},
$$

где $K_{m л}=O A / \kappa O-$ коэффициент текущей ликвидности; $K_{0}=\kappa O / Д З-$ коэффициент соотношения краткосрочных обязательств и дебиторской задолженности; $\kappa_{\partial}=$ ДЗ $/ К З-$ коэффициент соотношения дебиторской и кредиторской задолженностей; $K_{\kappa}=K 3 / 3 К-$ коэффициент соотношения кредиторской задолженности и заемного капитала.

Полученная семифакторная модель позволяет определить влияние на рентабельность чистых активов разнообразных факторов, характеризующих как степень использования активов организации, так и степень ее финансовой устойчивости.

Большое аналитическое значение имеют соотношения, рассчитываемые на основе стоимости чистых активов. В процессе анализа необходимо обратить внимание на показатели, представленные в табл. 2 (показаны для акционерных обществ в соответствии ФЗ «Об акционерных обществах») [12, с. 88].

\begin{tabular}{|c|c|}
\hline Показатель & Характеристика \\
\hline $\begin{array}{l}\text { Разница между стоимостью чистых акти- } \\
\text { вов общества и уставным капиталом }\end{array}$ & $\begin{array}{l}\text { Максимальная величина потерь и изъятий, ко- } \\
\text { торую может выдержать общество, прежде чем } \\
\text { придется уменьшать уставный капитал (ст. 35) }\end{array}$ \\
\hline $\begin{array}{l}\text { Разница между стоимостью чистых } \\
\text { активов и суммой уставного капитала и } \\
\text { резервного фонда общества }\end{array}$ & $\begin{array}{l}\text { Потенциальная возможность увеличения устав- } \\
\text { ного капитала за счет имущества (ст. 28) }\end{array}$ \\
\hline $\begin{array}{l}\text { Разница между стоимостью чистых } \\
\text { активов общества и суммой уставного } \\
\text { капитала, резервного фонда общества и } \\
\text { превышения над номинальной стоимо- } \\
\text { стью, определенной уставом общества, } \\
\text { ликвидационной стоимости размещенных } \\
\text { привилегированных акций }\end{array}$ & $\begin{array}{l}\text { Потенциальная возможность принимать решение } \\
\text { о выплате дивидендов (ст. 43). } \\
\text { Потенциальная возможность выплачивать диви- } \\
\text { денды (ст. } 43 \text { ). } \\
\text { Потенциальная возможность общества приобре- } \\
\text { тать свои акции (ст. } 73 \text { ) }\end{array}$ \\
\hline $10 \%$ стоимости чистых активов общества & $\begin{array}{l}\text { Максимальная сумма средств, направляемых } \\
\text { обществом на выкуп акций (ст. 76) }\end{array}$ \\
\hline
\end{tabular}

Показатели, рассчитываелые на основе стоилости чистых активов

От этих соотношений зависит принятие важнейших для акционерного общества решений.

Таким образом, проблемы расчета и анализа чистых активов организации все еще остаются актуальными. Значение этого показателя при оценке финансового состояния организации неоспоримо. Следовательно, необходимо в кратчайшие

\section{Baikal Research Journal}


сроки на законодательном уровне закрепить решение дискуссионных положений относительно отдельных составляющих расчета чистых активов. При этом, по мнению авторов настоящей публикации, подход, реализованный при классификации доходов будущих периодов для целей расчета чистых активов является обоснованным, но нуждается в законодательном закреплении в документах, которыми осуществляется регулирование бухгалтерского учета. То есть мы полагаем, что те доходы будущих периодов, которые исключаются из расчета при оценке чистых активов, должны отражаться в составе капитала, а не обязательств организации, к которым должны быть отнесены лишь те составляющие доходов будущих периодов, которые и классифицируются именно как обязательства. В противном случае, мы получаем несоответствие между названием разделов форм бухгалтерской отчетности и их наполнением.

\section{Список использованной литературы}

1. Слободняк И. А. Учетно-аналитическая информация об оценочных обязательствах / И. А. Слободняк, Э. В. Грозина, Т. Л. Быкова // Экономика и управление: проблемы и решения. - 2014. - № 2. - С. 45-54.

2. Орлова О. Е. О чистых активах организации / О. Е. Орлова // Актуальные вопросы бухгалтерского учета и налогообложения. - 2015. - № 4. - С. 23-33.

3. Манохова С. В. В каких случаях применение счета 98 обоснованно? / С. В. Манохова // Торговля: бухгалтерский учет и налогообложение. - 2014. - № 12. - C. 8-20.

4. Луканина А. В. Анализ базовых категорий МСФО в рамках принципа приоритета содержания над формой / А. В. Луканина // Международный бухгалтерский учет. 2015. - № 32. - С. 28-40.

5. Алексеева Г. И. Проблемы учета доходов будущих периодов в условиях реформирования российского бухгалтерского учета / Г. И. Алексеева // Бухгалтер и закон. 2014. - № 4. - C. 2-6.

6. Алексеева Г. И. Актуальные проблемы бухгалтерского учета доходов будущих периодов / Г. И. Алексеева, Э. С. Алексеев // Международный бухгалтерский учет. - 2015. № 24. - С. 21-33.

7. Верещагин С. Чистые активы и порядок их расчета / С. Верещагин // Налоговый учет для бухгалтера. - 2015. - № 2. - С. 26-33.

8. Линейкина С. М. Стоимость чистых активов: новый порядок расчета / С. М. Линейкина // Промышленность: бухгалтерский учет и налогообложение. - 2014. — № 11 . C. $49-54$.

9. Адамайтис Л. А. Анализ финансовой отчетности. Практикум : учеб. пособие / Л. А. Адамайтис. - М. : Кнорус, 2007. - 400 с.

10. Анализ финансовой отчетности : учеб. пособие / под ред. О. В. Ефимовой, М. В. Мельник. - М. : Омега-Л, 2004. - 408 с.

11. Илышева Н. Н. Анализ финансовой отчетности коммерческой организации : учеб. пособие / Н. Н. Илышева, С. И. Крылов. - М. : Юнити-Дана, 2006. - 240 с.

12. Когденко В. Г. Экономический анализ : учеб. пособие / В. Г. Когденко. - М. : Юнити-Дана, 2012. - 392 с.

13. Маркарьян Э. А. Экономический анализ хозяйственной деятельности : учеб. пособие / Э. А. Маркарьян, Г. П. Герасименко, С. Э. Маркарьян. - М. : КноРус, 2010. - 536 с.

14. Пожидаева Т. А. Анализ финансовой отчетности : учеб. пособие / Т. А. Пожидаева. - М. : КноРус, 2007. - 320 с.

15. Шеремет А. Д. Методика финансового анализа деятельности коммерческих организаций / А. Д. Шеремет, Е. В. Негашев. - М. : Инфра-М, 2003. - 237 с.

16. Экономический анализ : учеб. для бакалавров / под ред. Н. В. Войтоловского, А. П. Калининой, И. И. Мазуровой. - М. : Юрайт, 2013. - 548 с.

17. Экономический анализ : учебник / под ред. Л. Т. Гиляровской. - М. : Юнити-Дана, 2002. - 615 с.

18. Сорокина Е. М. Анализ платежеспособности организации / Е. М. Сорокина, С. А. Макаренко. - Иркутск : Изд-во БГУЭП, 2009. - 230 с.

\section{Baikal Research Journal}




\section{References}

1. Slobodnyak I. A., Grozina E. V., T. L. Bykova T. L. Accounting and analytical information on estimated liabilities. Ekonomika $i$ upravlenie: problemy, resheniya $=$ Economics and Management: Problems and Solutions, 2014, no. 2, pp. 45-54. (In Russian).

2. Orlova O. E. On organization's net assets. Aktual'nye voprosy bukhgalterskogo ucheta $i$ nalogooblozheniya $=$ Topical Issues of Accounting and Taxation, 2015, no. 4, pp. 23-33. (In Russian).

3. Manokhova S. V. In what cases is using account 98 valid? Torgovlya: bukhgalterskii uchet i nalogooblozhenie $=$ Trade: Accounting and Taxation, 2014, no. 12, pp. 8-20. (In Russian).

4. Lukanina A. V. Analysis of the basic categories of IFRS within the substance-overform concept. Mezhdunarodnyi bukhgalterskii uchet = International Accounting, 2015, no. 32, pp. 28-40. (In Russian).

5. Alekseyeva G. I. Problems of accounting incomes of future periods in terms of Russia's accounting reforming. Bukhgalter $i$ zakon = The Accountant and Law, 2014, no. 4, pp. 2-6. (In Russian).

6. Alekseyeva G. I., Alekseyev E. S. Topical issues of deferred income accounting. Mezhdunarodnyi bukhgalterskii uchet = International Accounting, 2015, no. 24, pp. 21-33. (In Russian).

7. Vereshchagin S. Net assets and their account settlement. Nalogovyi uchet dlya bukhgaltera = Tax Accounting for Accountants, 2015, no. 2, pp. 26-33. (In Russian).

8. Lineikina S. M. Net assets cost: new calculation procedure. Promyshlennost: bukhgalterskii uchet $i$ nalogooblozhenie = Industry: Accounting and Taxation, 2014, no. 11, pp. 49-54. (In Russian).

9. Adamaitis L. A. Analiz finansovoi otchetnosti [Financial Statements Analysis]. Moscow, KnoRus Publ., 2007. 400 p.

10. Efimov O. V., Mel'nik M. V. (eds). Analiz finansovoi otchetnosti [Financial Statements Analysis]. Moscow, Omega-L Publ., 2004. 408 p.

11. Ilysheva N. N., Krylov S. I. Analiz finansovoi otchetnosti kommercheskoi organizatsii [Analysis of Financial Statements of Commercial Organizations]. Moscow, Yuniti-Dana Publ., 2006. $240 \mathrm{p}$.

12. Kogdenko V. G. Ekonomicheskii analiz [Economic Analysis]. Moscow, Yuniti-Dana Publ., 2012. 392 p.

13. Markaryan E. A., Gerasimenko G. P., Markaryan S. E. Ekonomicheskii analiz khozyaistvennoi deyatel'nosti [Economic Activities Analysis]. Moscow, KnoRus Publ., 2010. 536 p.

14. Pozhidayeva T. A. Analiz finansovoi otchetnosti [Financial Statements Analysis]. Moscow, KnoRus Publ., 2007. 320 p.

15. Sheremet A. D., Negashev E. V. Metodika finansovogo analiza kommercheskikh organizatsii [Methods of financial analysis of commercial organizations]. Moscow, Infra-M Publ., 2003. 237 p.

16. Voitolovsky N. V., Kalinina A. P., Mazurova I. I. (eds). Ekonomicheskii analiz [Economic Analysis]. Moscow, Yurait Publ., 2013. 548 p.

17. Gilyarovskaya L. T. (ed.). Ekonomicheskii analiz [Economic Analysis]. Moscow, Yuniti-Dana Publ., 2002. 615 p.

18. Sorokina Ye. M., Makarenko S. A. Analiz platezhesposobnosti organizatsii [Company's Solvency Analysis]. Irkutsk, Baikal State University of Economics and Law Publ., 2009. 230 p.

\section{Информация об авторах}

Слободняк Илья Анатольевич - доктор экономических наук, доцент, заведующий кафедрой бухгалтерского учета, анализа, статистики и аудита, Байкальский государственный университет, 664003, г. Иркутск, ул. Ленина, 11, e-mail: slob.irk@mail.ru.

Грозина Эльвира Васильевна - кандидат экономических наук, доцент, кафедра бухгалтерского учета, анализа, статистики и аудита, Байкальский государственный университет, 664003, г. Иркутск, ул. Ленина, 11, e-mail: sea@isea.ru.

Фадеева Анна Анатольевна - кандидат экономических наук, доцент, кафедра бухгалтерского учета, анализа, статистики и аудита, Байкальский государственный университет, 664003, г. Иркутск, ул. Ленина, 11, e-mail: faa15@mail.ru.

\section{Baikal Research Journal}




\section{Authors}

Ilya A. Slobodnyak - Doctor habil. (Economics), Associate Professor, Head of Chair of Accounting, Analysis, Statistics and Audit, Baikal State University, 11 Lenin St., 664003, Irkutsk, Russian Federation; e-mail: slob.irk@mail.ru.

Elvira V. Grozina - PhD in Economics, Associate Professor, Chair of Accounting, Analysis, Statistics and Audit, Baikal State University, 11 Lenin St., 664003, Irkutsk, Russian Federation; e-mail: sea@isea.ru.

Anna A. Fadeeva - PhD in Economics, Associate Professor, Chair of Accounting, Analysis, Statistics and Audit, Baikal State University, 11 Lenin St., 664003, Irkutsk, Russian Federation; e-mail: faa15@mail.ru.

\section{Библиографическое описание статьи}

Слободняк И. А. Проблемы расчета и анализа чистых активов организаций / И. А. Слободняк, Э. В. Грозина, А. А. Фадеева // Baikal Research Journal. — 2016. — Т. 7, № 6. DOI: $10.17150 / 2411-6262.2016 .7(6) .1$.

\section{Reference to article}

Slobodnyk I. A., Grozina E. V., Fadeeva A. A. Problems of calculating and analyzing organizations' net assets. Baikal Research Journal, 2016, vol. 7, no. 6. DOI: 10.17150/24116262.2016.7(6).1. (In Russian).

\section{Baikal Research Journal}

